\title{
Holocene floodplain evolution in a central European loess landscape - geoarchaeological investigations of the lower Pleiße valley in NW Saxony
}

\author{
Christian Tinapp $^{1,4}$, Susann Heinrich ${ }^{2}$, Christoph Herbig ${ }^{3}$, Birgit Schneider ${ }^{1}$, Harald Stäuble ${ }^{4}$, Jan Miera ${ }^{5}$, and \\ Hans von Suchodoletz ${ }^{6,1}$ \\ ${ }^{1}$ University of Leipzig, Institute of Geography, Johannisallee 19a, 04103 Leipzig, Germany \\ ${ }^{2}$ Max-Planck-Institute for Evolutionary Anthropology, Deutscher Platz 6, 04103 Leipzig, Germany \\ ${ }^{3}$ Am Dorf 12, 63517 Rodenbach, Germany \\ ${ }^{4}$ Saxonian Archaeological Heritage Office, Zur Wetterwarte 7, 01109 Dresden, Germany \\ ${ }^{5}$ University of Leipzig, Historical Seminar, Ritterstraße 14, 04109 Leipzig, Germany \\ ${ }^{6}$ University of Technology Dresden, Institute of Geography, Helmholtzstraße 10, 01069 Dresden, Germany
}

Correspondence: Christian Tinapp (christian.tinapp@lfa.sachsen.de)

Relevant dates: $\quad$ Received: 8 March 2019 - Revised: 17 May 2019 - Accepted: 13 June 2019 Published: 15 July 2019

How to cite:

Tinapp, C., Heinrich, S., Herbig, C., Schneider, B., Stäuble, H., Miera, J., and von Suchodoletz, H.: Holocene floodplain evolution in a central European loess landscape - geoarchaeological investigations of the lower Pleiße valley in NW Saxony, E\&G Quaternary Sci. J., 68, 95-105, https://doi.org/10.5194/egqsj-68-95-2019, 2019.

Abstract:

Undisturbed sediments are an important source for the reconstruction of the Holocene development of valleys. Wide floodplains with relatively small rivers in a region settled since $5500 \mathrm{BCE}$ offer opportunities for investigations regarding climatic and anthropogenic landscape change. In the context of a motorway construction, excavations were carried out by the Saxonian Heritage Office in the year 2015. At one of the sites it was possible to get a view of the sediments of the Pleiße valley less than $100 \mathrm{~m}$ distance from large cross sections described by Neumeister (1964) in a former open cast mine. Archaeological finds and features, plant remains and radiocarbon dating as well as micromorphological and geochemical investigations helped to decipher the age and the characteristics of the Holocene sediments: above Weichselian loamy sands a sedge peat developed in small depressions during the Preboreal and Boreal. The sands and the sedge peat are covered by a "black clay", which was still the topsoil during the Atlantic period. The sedimentation of $2.3 \mathrm{~m}$ thick overbank fines began after 4000 BCE. A depth of $1 \mathrm{~m}$ below the surface a medieval Slavic find layer was excavated. These results show that sedimentation processes in the lower Pleiße valley significantly changed after $4000 \mathrm{BCE}$. It is obvious that the increase in silty material in the floodplain is caused by the land clearance in the Neolithic period. More than half of the silty overbank fines were deposited before the Middle Ages began.

Kurzfassung: Ungestörte Sedimente in fluvialen Systemen sind ein wichtiges Archiv zur Rekonstruktion der holozänen Talentwicklung. Seit 5500 BCE besiedelte Altsiedellandschaften mit breiten, von relativ kleinen Flüssen durchflossenen Tälern bieten besonders gute Voraussetzungen für die Untersuchung klimatis- 
cher und anthropogener Einflüsse auf Landschaftsveränderungen. Im Rahmen eines Autobahnprojektes südlich von Leipzig wurden vom Landesamt für Archäologie Sachsen Ausgrabungen durchgeführt. An einer der Grabungsflächen konnten die Sedimente des Pleißetales in weniger als $100 \mathrm{~m}$ Entfernung zu den von Neumeister (1964) in einem Tagebau beschriebenen Profilen aufgenommen und beprobt werden. Archäologische Befunde und Funde, Pflanzenreste, Radiocarbondatierungen, mikromorphologische und geochemische Untersuchungen führten zur Eingrenzung des Alters der holozänen Sedimente: Über weichselzeitlichem lehmigen Sand lagern in kleinen Vertiefungen Seggentorflagen aus dem Präboreal und Boreal. Sand sowie Torf werden von einem "Schwarzen Ton" überdeckt, der bis weit in das Atlantikum hinein den Oberboden bildete. Nach 4000 BCE begann die Sedimentation von etwa 2,3 m Auenlehm. Einen Meter unter der Geländeoberfläche befindet sich eine mittelalterliche, slawische Fundschicht. Die Ergebnisse belegen, dass sich nach der Ankunft der ersten Ackerbauern die Sedimentationsprozesse im Tal der unteren Pleiße nach 4000 BCE signifikant änderten. Der deutliche Anstieg von schluffreicherem Material in der Aue geht auf die Unterkulturnahme weiter Teile des Einzugsgebietes im Neolithikum zurück. Mehr als die Hälfte der Auenlehmdecke entstand vor dem Mittelalter.

\section{Introduction}

Alluvial valley sediments are important archives of the Holocene landscape evolution, since besides internal processes the dynamics of rivers are controlled by external factors such as base level changes, tectonic activity, climate changes and anthropogenic activity (Bridgland and Westaway, 2008; Faust and Wolf, 2017). Therefore, to investigate the Holocene landscape evolution of central Europe, alluvial sediments of several rivers have been studied during recent years (Starkel et al., 2006; Hoffmann et al., 2008; Erkens et al., 2009; Kaiser et al., 2012; Houben et al., 2013; Notebaert et al., 2018).

Considering central Germany with a long settlement history since ca. $7.5 \mathrm{ka}$ (Heynowski and Reiß, 2010), only sediments of the lower Weiße Elster River were intensively studied during recent decades (Händel, 1967; Hiller et al., 1991; Fuhrmann, 1999; Tinapp, 2002; Tinapp et al., 2008). However, given that the fluvial dynamics can show individual behaviour even between neighbouring river systems (Faust and Wolf, 2017; von Suchodoletz et al., 2018a), the results from the lower Weiße Elster should ideally be complemented by investigations from other regional river systems to derive sound conclusions about the regional paleoenvironmental evolution. Generally, the Holocene landscape evolution of central Germany is not well known so far: besides investigations of the alluvial sediments from the lower Weiße Elster valley, current knowledge is based on non-continuous pollen, snail or ostracod data from different archives, as well as on lacustrine sediments from the former lake Salziger See (Litt, 1992; Mania, 1980; Fuhrmann, 2008; Wennrich et al., 2005).

In contrast to the Weiße Elster River, the lower part of its eastern tributary Pleiße has rarely been investigated so far (Neumeister, 1964; Händel, 1967). According to Neumeister (1964) the stratigraphy for large parts of the lower Pleiße valley is as follows: the base is formed by Late Weichselian silty fine sand that is sporadically covered by peat, and both are covered by a so-called "black clay" ("Schwarzer Ton"; Neumeister, 1964) that is overlain by older and younger overbank fines. New geoarchaeological investigations of a longknown site in the lower Pleiße valley in 2015 offered the chance to re-evaluate and reanalyse the fluvial stratigraphy of the lower Pleiße valley with modern radiocarbon, sedimentological and micromorphological methods.

Therefore, the goal of this study was to reconstruct environmental change in the lower Pleiße floodplain and to compare these results with those from the neighbouring lower Weiße Elster valley (Figs. 1 and 2) but also with other floodplains from central Europe. This will allow sound conclusions about the regional paleoenvironmental evolution of central Germany compared with other regions of central Europe.

\section{Study area}

The area south of Leipzig belongs to the North German Plain, and the mostly flat landscape is covered with Pleistocene sediments: in the northern part, glacial till, gravel and sand deposits of Elsterian and Saalian age are covered by Weichselian sandy loess with a thickness of ca. $50 \mathrm{~cm}$. Towards the south, the sandy loess grades into typical loess and increases its thickness to more than $7 \mathrm{~m}$ in the Altenburg-Zeitz loess hills (Eissmann, 2002).

The once $115 \mathrm{~km}$ long Pleiße River is a right-hand tributary of the Weiße Elster. Most of its former valley was destroyed by mining activities during the 20th century. Therefore the river flows through a canal today, and only small parts of its original floodplain are still preserved. The courses of the Weiße Elster and Pleiße River were formed during the Elsterian glaciation more than 400000 years ago (Eissmann, 2002; Lauer and Weiss, 2018). Subsequently, fluvial gravels and sand were deposited under periglacial conditions 


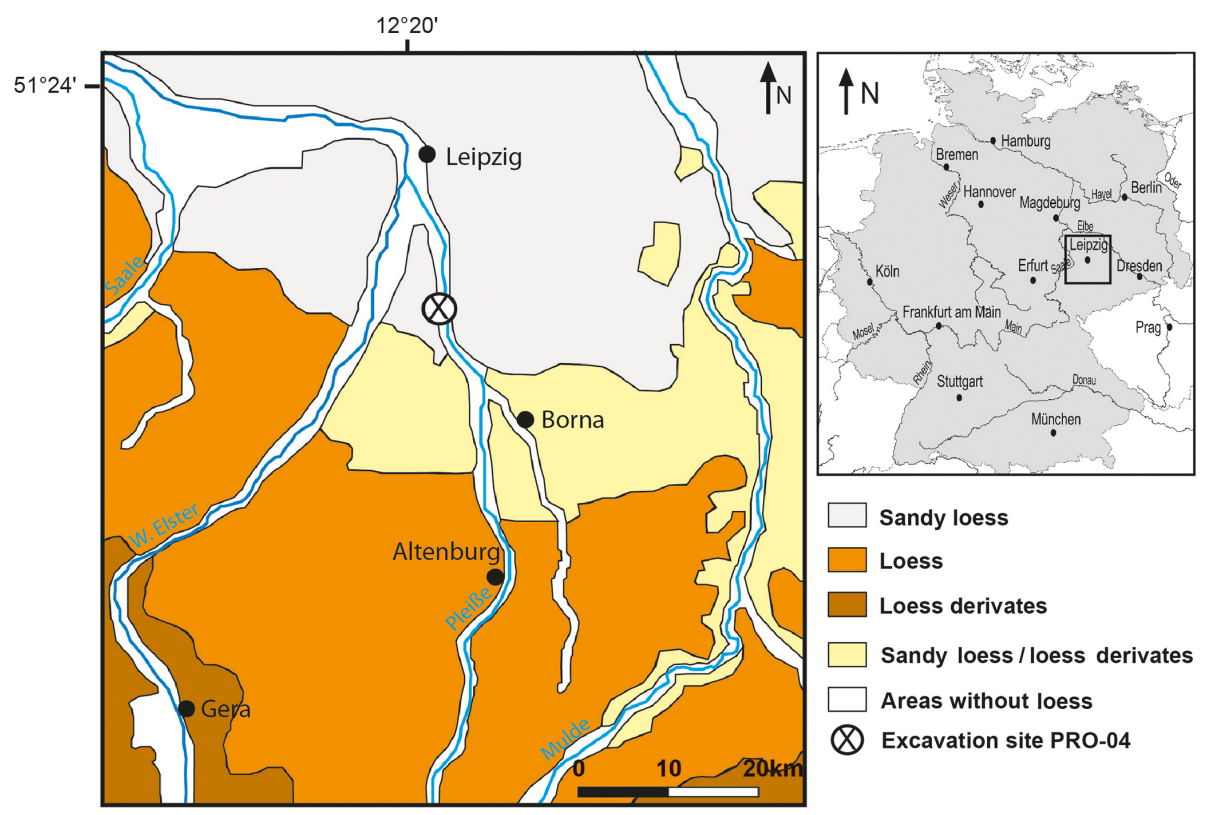

Figure 1. The excavation site near the Pleiße River south of Leipzig with the distribution of loess and loess-like deposits (according to Eissmann, 2002).

during the Saalian and Weichselian glacial periods. In both river systems the current floodplains are found at the eastern sides of the once wider valleys, whereas the western parts are mainly occupied by Saalian gravel terraces. In the remaining smaller floodplains Weichselian gravels and sands form the bases of the Holocene deposits. The branched Weichselian river systems changed towards meandering systems during the latest Weichselian period (Mol, 1995). After the Younger Dryas cold spell, the so far dominant steppe vegetation was replaced by open forests that developed in the floodplains and the surrounding areas (Litt, 1994). The first Neolithic settlers already arrived in the region 7500 years ago (Heynowski and Reiß, 2010). This was the start of a long history of land use in the region with varying intensities during different periods (Tinapp and Stäuble, 2000).

\section{Methods}

In the context of a motorway construction, archaeological excavations were carried out by the Saxonian Heritage Office in 2015. In one of the four excavation sites east of the village Großdeuben, sediments of the lower Pleiße floodplain were exposed probably less than $100 \mathrm{~m}$ distance from the cross sections that were described by Neumeister (1964) in the open cast lignite mine Espenhain more than 50 years ago.

In preparation for the excavation, the topsoil was removed in a $20 \times 83 \mathrm{~m}$ wide area by an excavator up to $1 \mathrm{~m}$ below the current surface. At this level a small channel and a lot of Slavic remnants (900-1000 CE) were discovered. During the excavations of the Slavic features three cross sections were opened by the excavator: Profile 1 was $15 \mathrm{~m}$ long and $2.1 \mathrm{~m}$ deep, and Profile 2 was $10 \mathrm{~m}$ long and $1.8 \mathrm{~m}$ deep. Both eastwest directed parallel cross sections started on the level of the Slavic features, while the smaller ( $2 \mathrm{~m}$ long) and $1.6 \mathrm{~m}$ deep Profile 3 was dug at the edge of the excavation area (Fig. 3). From the sediments in Profile 3, 6 samples were taken for geochemical analyses, and in Profile 2, 22 samples were taken for geochemical analyses and another 6 for radiocarbon dating. In Profile 1, 1 sample was taken for thin section analysis.

Plant macro remains were extracted from two sediment samples each in Profile 1 and 2 by flotation and wet sieving (mesh width: 2, 0.5 and $0.25 \mathrm{~mm}$ ), and determined under magnifications from $\times 6.3$ to $\times 40$ using standard literature (e.g. Cappers et al., 2012) and the reference collection at the Laboratory of Archaeobotany, Institute of Prehistoric Archaeology, Goethe University Frankfurt. Attribution of the taxa to ecological units followed Oberdorfer (2001). Several discovered fruits and seeds, as well as pieces of charcoal from two layers of the overbank fines under the Slavic surface at Profile 2, were used for radiocarbon dating (Table 1).

A thin section for micromorphological analysis was prepared from an oriented and undisturbed soil sample taken from the transition of the black clay to the overlying overbank deposits in Profile 1 and was impregnated with resin. The thin section was analysed using a petrographic microscope under plane-polarized light (PPL), crossed polarized light (XPL) and oblique incident light (OIL). The microscopic description mainly followed the terminology according to Bullock et al. (1985) and Stoops (2003).

The particle size distribution was determined by dry sieving of the sand fraction, and silt and clay were measured 


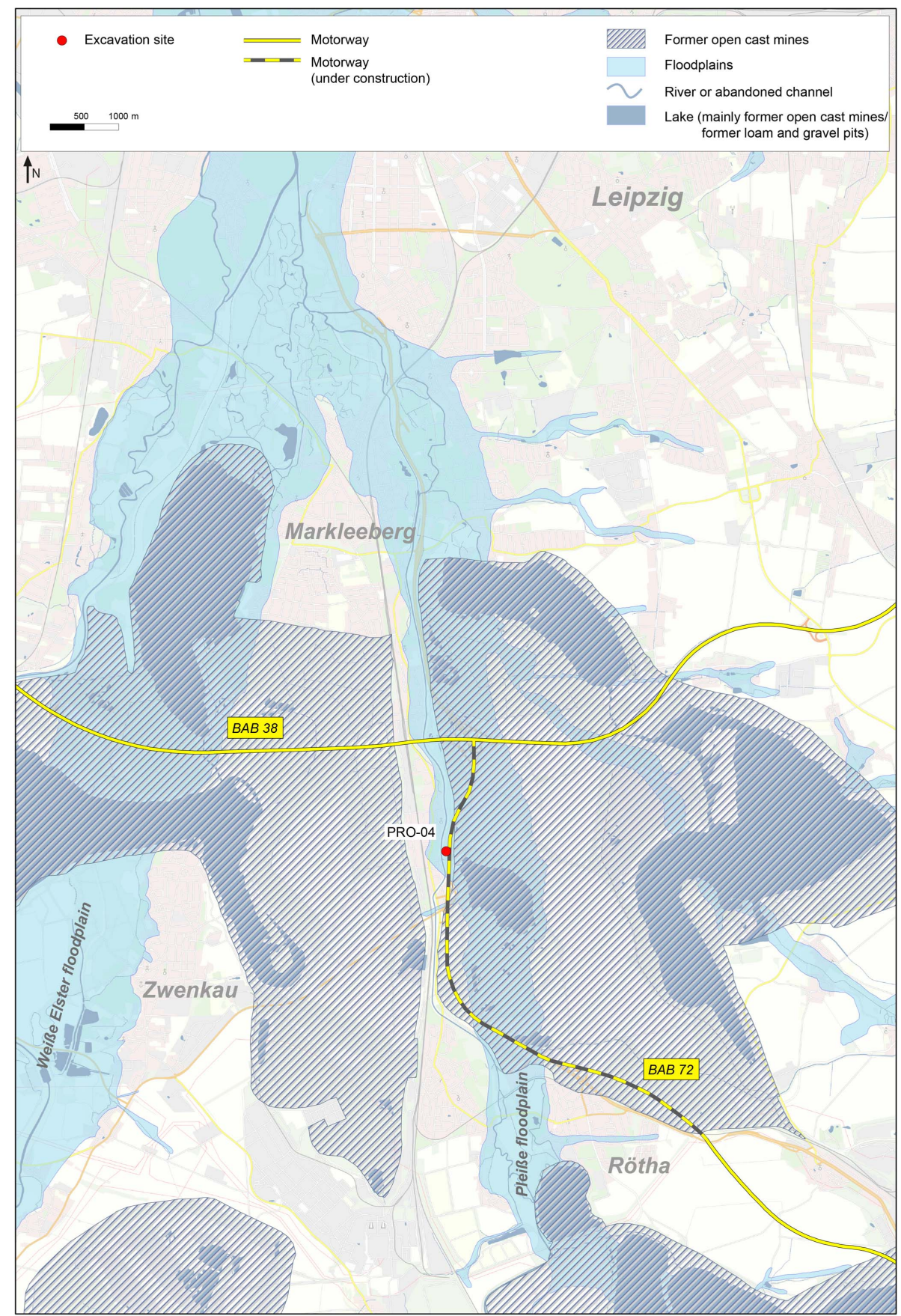

Figure 2. Location of the excavation site (PRO-04) with mining areas and the floodplains of Weiße Ester and Pleiße (map: Geodaten@ Staatsbetrieb Geoinformation und Vermessung Sachsen 2018).

based on settling velocities using a sedigraph (Micrometrics). An element analyser was used for the determination of the total contents of carbon, nitrogen and sulfur. The determination of the carbonate content was carried out using the volumetric method with a Eijkelkamp calcimeter according to Scheibler. Subtraction of the inorganic carbon from the total carbon resulted in the organic carbon.

\section{Results}

In the following, the stratigraphic succession of the lower Pleiße valley with analytical and dating results is described from the base to the top (Fig. 4):

- The base of the Holocene floodplain is formed by Late Weichselian loamy sands. These are waterlogged and do 
Table 1. Results of ${ }^{14} \mathrm{C}$ analyses, performed by Ronny Friedrich, Curt-Engelhorn-Zentrum Archäometrie in Mannheim (CEZ), and calibrated using INTCAL 13 and SwissCal 1.0.

\begin{tabular}{llrrrrrr}
\hline MAMS & Material & $\begin{array}{r}{ }^{14} \mathrm{C} \text { age } \\
\text { (years) }\end{array}$ & $\begin{array}{r}\text { Error } \\
\text { (years) }\end{array}$ & $\begin{array}{r}\delta^{13} \mathrm{C} \\
\left({ }^{0} / 00\right)\end{array}$ & $\begin{array}{r}1 \sigma \\
\text { Cal. BCE (years) }\end{array}$ & $\begin{array}{r}2 \sigma \\
\text { Cal. BCE (years) }\end{array}$ & $\begin{array}{r}\mathrm{C} \\
(\%)\end{array}$ \\
\hline 27110 & peat & 9876 & 35 & -25.0 & $9353-9283$ & $9402-9265$ & 52.8 \\
27111 & charcoal & 9408 & 34 & -30.7 & $8730-8638$ & $8785-8612$ & 59.7 \\
27112 & wood fragments & 8702 & 33 & -26.6 & $7736-7613$ & $7811-7599$ & 56.4 \\
27113 & wood fragments & 5152 & 27 & -27.7 & $3984-3951$ & $4038-3816$ & 51.5 \\
27114 & charcoal & 4474 & 27 & -31.7 & $3327-3095$ & $3337-3029$ & 2.2 \\
27115 & charcoal & 3604 & 25 & -28.1 & $2015-1924$ & $2026-1895$ & 38.4 \\
\hline
\end{tabular}

not contain any organic remnants, with the exception of fine roots.

- The loamy sands are sporadically covered by peat layers, where $C_{\text {org }}$ values reach $>30 \%$, and the $\mathrm{pH}$ is $<3$ (Fig. 5). The peat is compacted and contains plant material mostly consisting of Carex species. Other plants which could be identified were Betula spec. and some herbs like Comarum palustre and Filipendula ulmaria, indicating the existence of a Carex peat. Radiocarbon dates prove a Preboreal age of the peat layers (Fig. 4 and Table 1): peat fragments date between 9402 and $9265 \mathrm{cal}$. BCE, while the charcoal has a younger age of 8785-8612 cal. BCE. In contrast, dated wood pieces probably have their origin in roots and are about 1000 years younger.

- A black clay ca. $25 \mathrm{~cm}$ thick covers the loamy sand and the peat. Clay contents $>80 \%$ demonstrate calm sedimentation conditions during its deposition. $\mathrm{pH}$ values rise to $>4$, and $C_{\text {org }}$ values are $>6 \%$. Root traces start at the top and pass downwards through the black clay layer. Plant macro remains could not be found, with the exception of root fragments and one charcoal piece. The root fragments gave a radiocarbon age of 40383816 cal. BCE (Fig. 4). The lowest part of the thin section, representing the upper part of the black clay, was made up of dark-grey-coloured, very fine-grained material (fine silt and clay). The microstructure of the sediment was spongy, as it mainly consisted of more or less oval and round-shaped voids that were encircled by filigree sediment covers and bridges between the covered voids (Fig. 6a, b). Their shape implies its genesis by plant pseudomorphs: plants (stems) were embedded into the sediments and subsequently completely decomposed so that only the embedding material was preserved. Plants standing upright would have created vertical structures. Therefore, the horizontal pseudomorphs suggest a surface-parallel bedding of the plant stems. This process is regularly observed during flood events. Obviously, the thin section illustrates the remnants of the last vegetation that covered the black clay before the deposition of overbank fines began.

- The black clay is overlain by overbank fines with a thickness of ca. $2.3 \mathrm{~m}$. The deposits directly overlying the black clay already have a much higher silt content, while clay percentages drop from $80 \%$ to around $50 \%$ (Fig. 5). The colour changes from black (2.5Y2.5/1) to dark greyish brown (10YR4/2), while the $\mathrm{pH}$ values are between 4 and 5 . The $C_{\text {org }}$ content of the overbank fines fluctuates between $0.5 \%$ and $1 \%$, and redoximorphic features prove temporal waterlogging. Charcoal pieces were taken from two levels of the overbank fines of Profile 2, i.e. at 117.1 and $117.8 \mathrm{~m}$ a.s.l. (Fig. 4). Both radiocarbon ages prove a Subboreal age (3337-3029, 20261895 cal. BCE; Table 1). The upper part of the thin section, representing the lowest overbank fines, shows closely packed fine-grained sediments. The material has a light grey colour with dark-grey-coloured channel infillings, consisting of the underlying black clay that was mixed in by bioturbation (Fig. 6). Furthermore, abundant biogenic voids underline a high intensity of bioturbation processes. The grey colour of the sediments is mainly a consequence of reducing conditions due to a high groundwater level. Nevertheless, the thin section reveals features of groundwater oscillations: larger voids allowing oxygen intrusion into the sediment display coatings, hypocoatings and fibrous crystals of ferric oxides and hydroxides (Fig. 6e, f).

- Above the lower level of overbank fines with an Atlantic to Subboreal age, a lot of potsherds of the Slavic period (ca. 900-1000 CE) mark the base of ca. $1 \mathrm{~m}$ of loamy material that was deposited during the last ca. 1000 years (Fig. 3). Higher sand values below and above the Slavic layer prove less calm conditions during the sedimentation process (Fig. 5). Missing settlement features give evidence for just a short period of human activity on the valley floor during the Slavic period. 


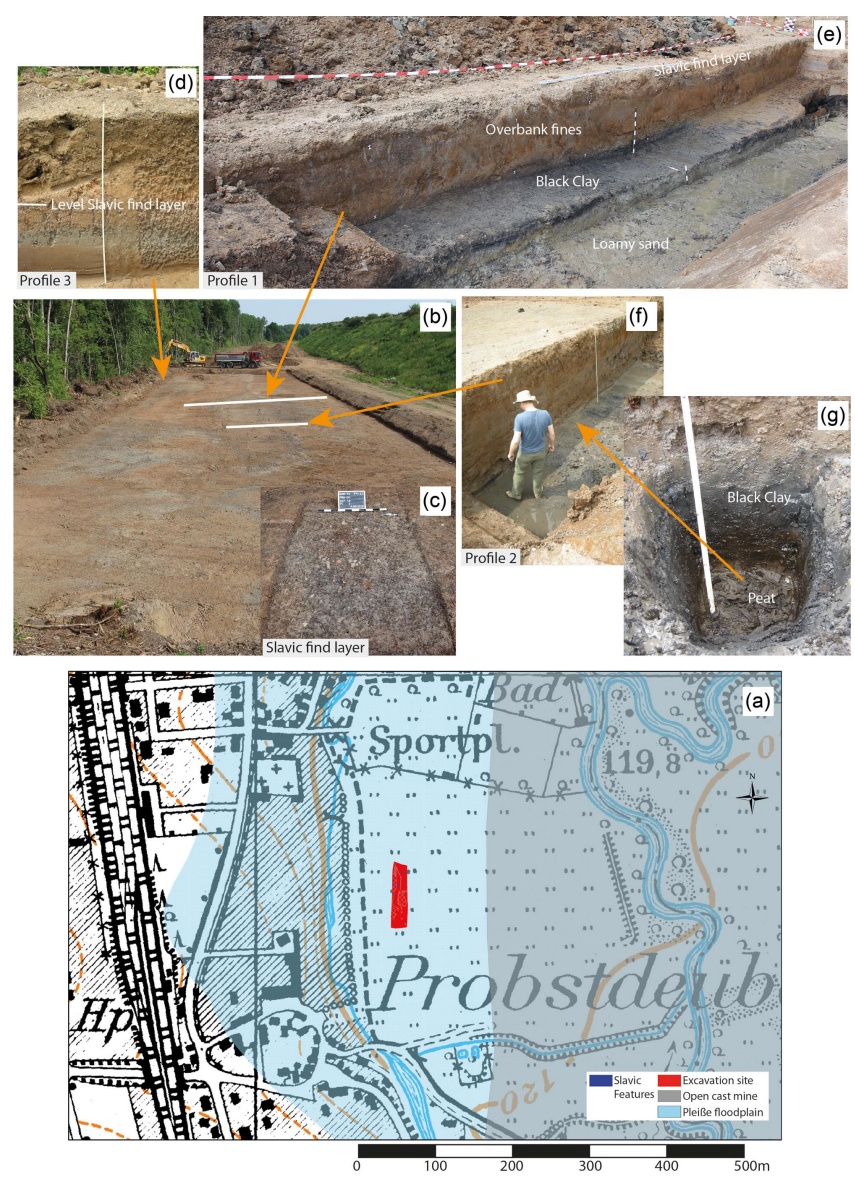

Figure 3. The excavation site, the profiles and the sediments near Probstdeuben. (a) The excavation site in the floodplain and the topographic situation during the first half of the last century (Geodaten@ Staatsbetrieb Geoinformation und Vermessung Sachsen 2018). (b) The excavation site after removal of ca. $1 \mathrm{~m}$ of overbank fines by an excavator with the positions of the three profiles. (c) Slavic finds in the overbank fines ca. $1 \mathrm{~m}$ below the recent surface. (d) The uppermost overbank fines with the level of the Slavic find layer in Profile 3. (e) Profile 1 with the waterlogged loamy sands that are covered by the black clay and overbank fines. (f) Profile 2 with the black clay at the bottom. In a small hand-dug pit beneath the base of the profile a peat layer was found under the black clay $(\mathbf{g})$.

\section{Discussion}

\subsection{Deposition of peat and black clay sediments during the Early to Middle Holocene}

The oldest Holocene sediments in the lower Pleiße valley are peats that developed in small depressions of the Weichselian valley floor during the Preboreal period (Fig. 7a). Similar layers were formerly also described by Neumeister (1964) and Händel (1967). Organic sediments in the same stratigraphic position are also known from the lower Weiße Elster valley (Hiller et al., 1991; Tinapp, 2002), and organic deposition since that period is also known from other European catch-

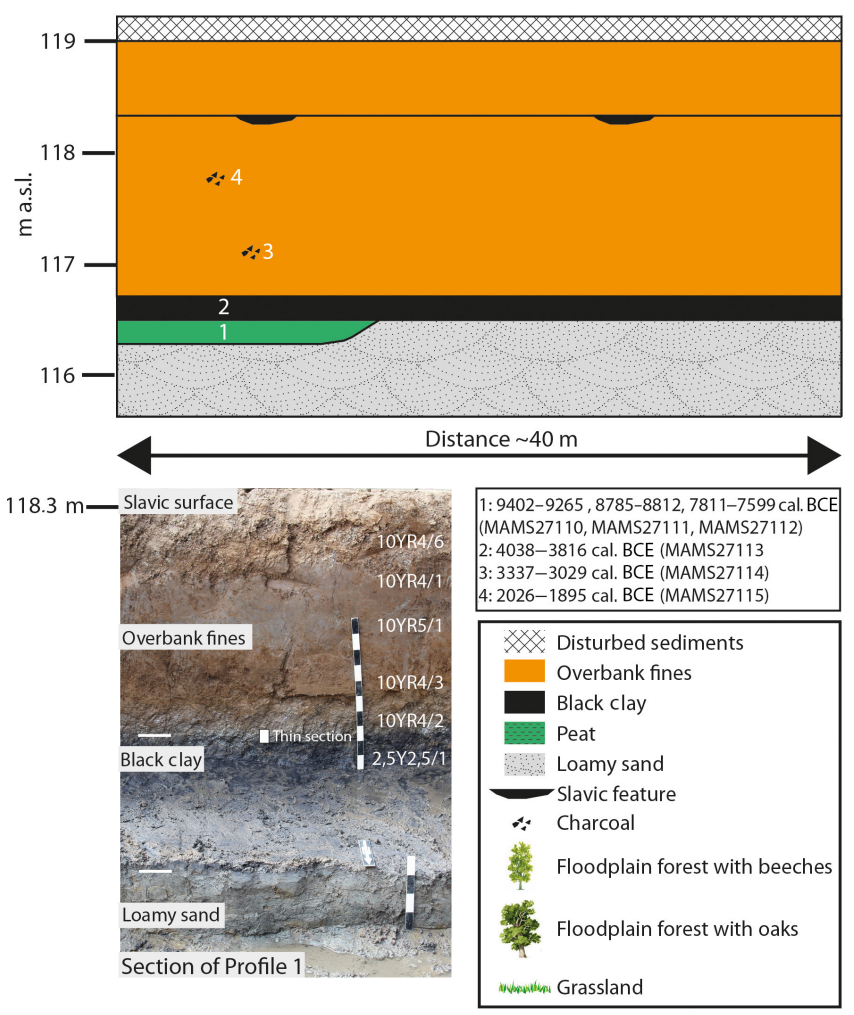

Figure 4. The valley sediments of the Pleiße according to Profile 1 to 3 with ${ }^{14} \mathrm{C}$ ages and the position of the thin section.

ments (Rittweger, 2000; Notebaert et al., 2018). Probably wetter conditions and higher groundwater levels in the valleys during the Preboreal resulted in the formation of many small peat layers on the Weichselian sediment base.

Sedimentation of the black clay in the Pleiße valley started during the Boreal and stopped during the Atlantic period when it was covered by overbank fines. According to the high clay content we assume mainly limnic conditions during the time of its sedimentation. According to Neumeister (1964) our investigations confirm that the black clay is pedologically a gyttja; i.e. it was formed under waterlogging conditions. The black clay discordantly covers the Weichselian sand and the Preboreal peat (Fig. 7b). Deposition of these more limnic sediments with a lower organic content during the Boreal compared with the Preboreal indicates a change towards more humid environmental conditions on the valley floor of the lower Pleiße River. However, iron and manganese features and roots that start in the black clay and reach the underlying loamy Weichselian sands also prove temporal drier periods. It is likely that the repeated changes of wetter and drier conditions on the valley floor were caused by fluctuations of the water table of the river. A similar black clay layer was not found in the neighbouring lower Weiße Elster river system. There, overbank fines directly cover Weichselian sand and gravel and sporadically also Preboreal peats (Hiller et al., 1991; Tinapp, 2002). We assume that the val- 

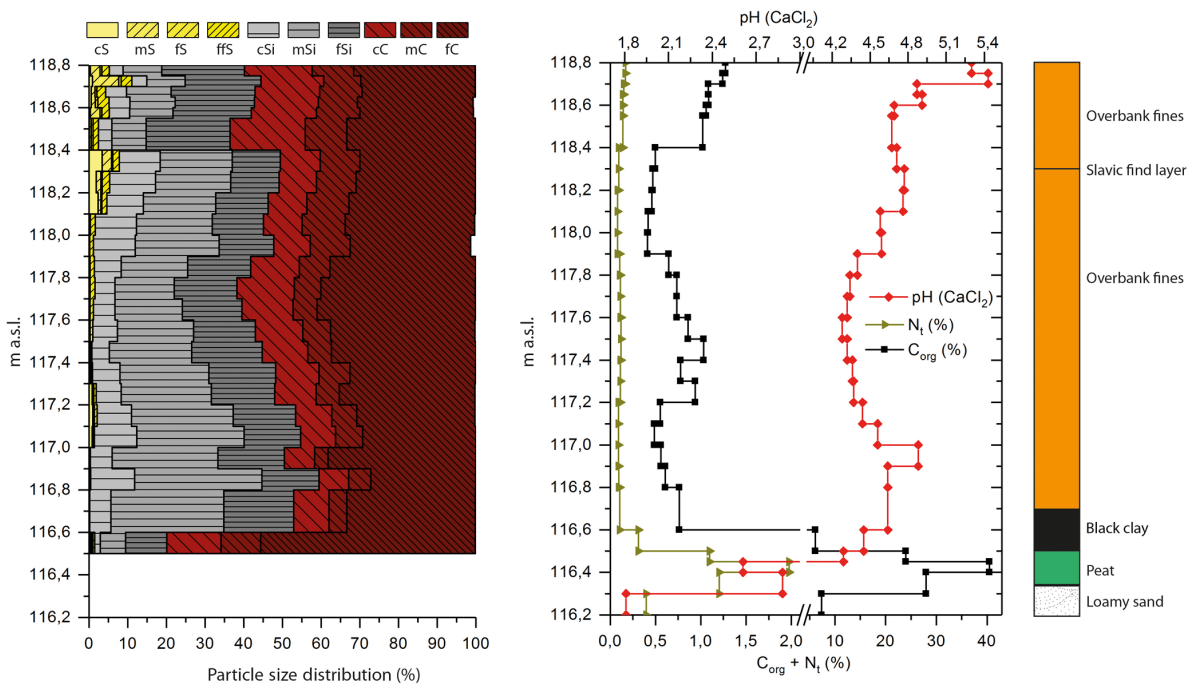

Figure 5. Particle size distribution, $\mathrm{pH}$ values and organic carbon of the sediments of Profile 1 to 3.
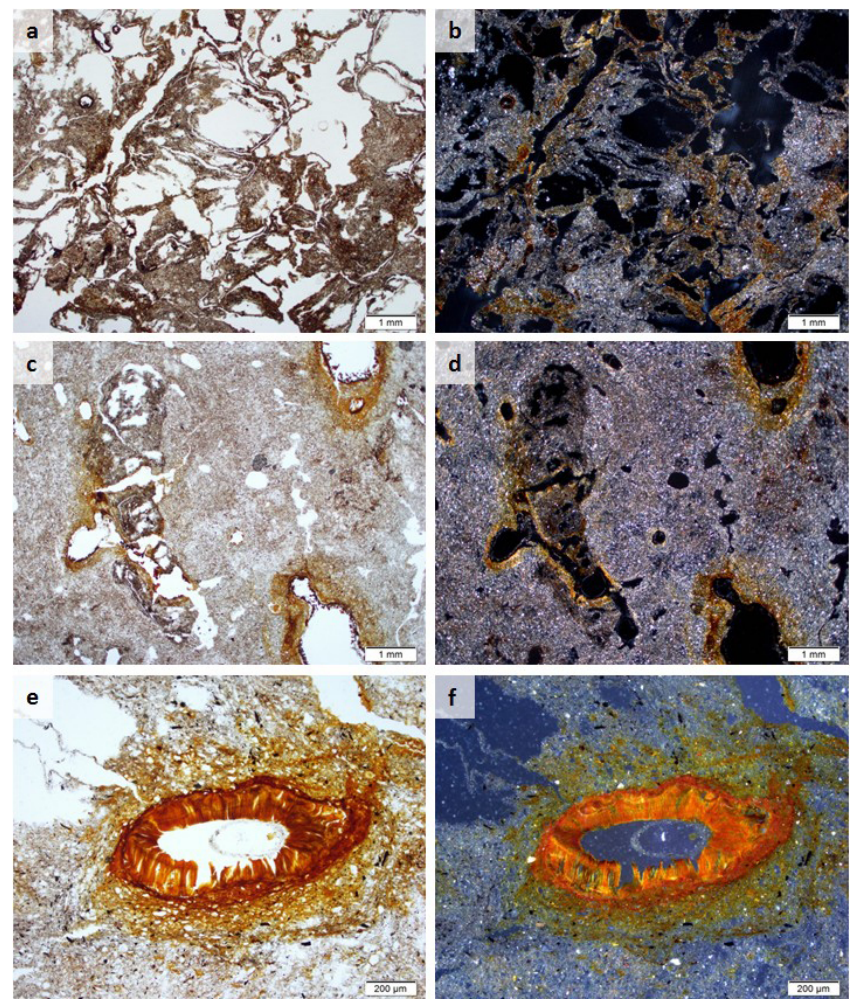

Figure 6. Microphotographs of the black clay (a, b) and the oldest overbank fines (c-f). (a) Voids encircled by filigree sediment covers and bridges between the covered voids (PPL). (b) Like (a) (XPL). (c) Light-grey-coloured material with dark-grey-coloured channel infillings consisting of the underlying black clay mixed in by bioturbation (PPL). (d) Like (c) (XPL). (e) Ferric coating, hypocoating and fibrous crystals of goethite (PPL). (f) Like (e) (OIL).

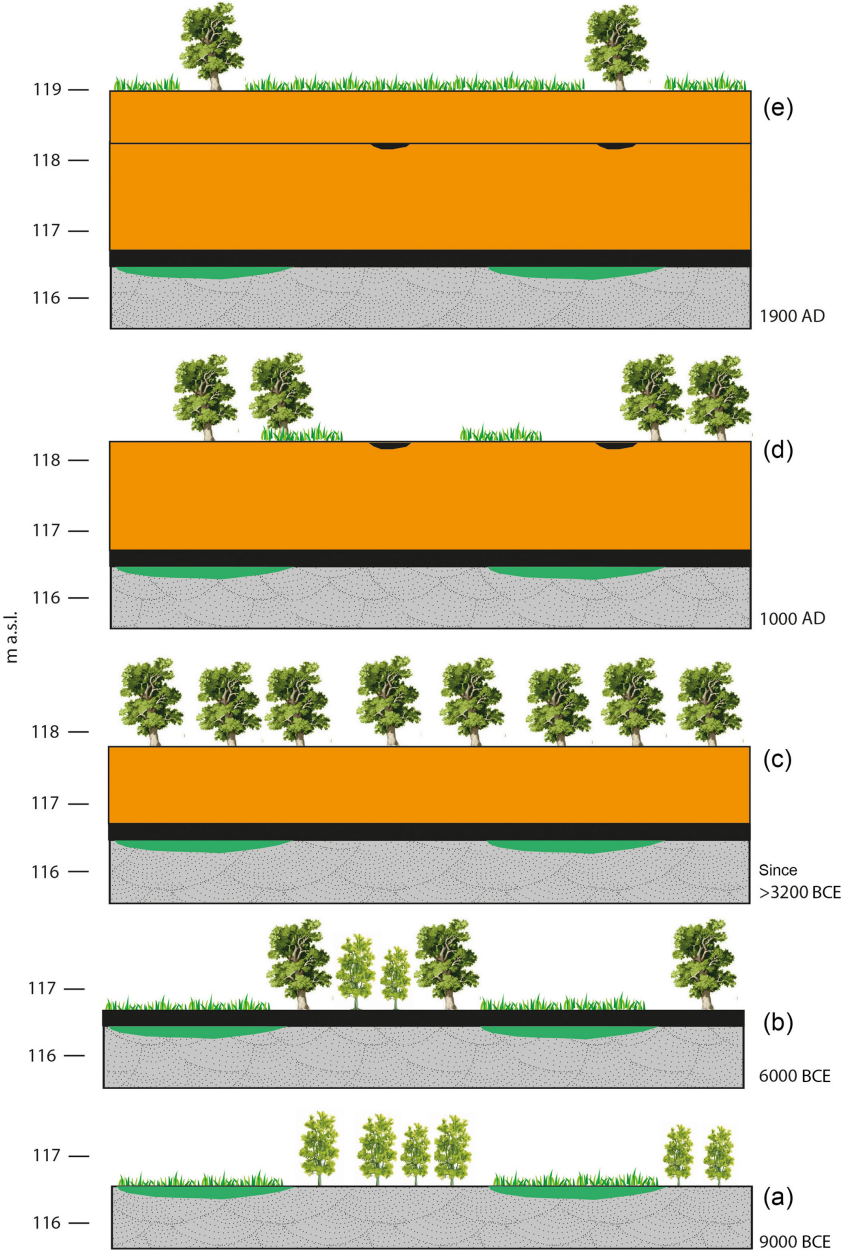

Figure 7. Holocene floodplain development of the lower Pleiße in five stages (legend in Fig. 4). 
ley of the lower Weiße Elster, $2 \mathrm{~km}$ wide, was better drained than the lower Pleiße valley with a width of only ca. $1 \mathrm{~km}$, and therefore a black clay could not develop in the former. It is also possible that the very slight slope of less than $1 \%$ from here towards the drainage base a few kilometres in the north that is formed by the Weiße Elster valley stimulated the temporary development of limnic conditions in the lower Pleiße valley, allowing the deposition of the black clay layer.

It can be questioned whether black Holocene floodplain sediments should generally be interpreted as "Black Floodplain Soils" (Rittweger, 2000). However, the widespread existence of black-coloured organic-rich and clayey sediments in the same stratigraphic positions of different loessinfluenced central European floodplains (Brunnacker, 1959; Schirmer, 1983; Bork, 1983; Brosche, 1984; Pretzsch, 1994; Schellmann, 1994; Hilgart, 1995; Rittweger, 2000; Bos et al., 2008; Brown et al., 2018) suggests similar conditions during the Boreal and Atlantic period for central Europe: wet valley floors and high organic load obviously caused the formation of clay-rich limnic layers with high contents of organic carbon. Rittweger (2000) discussed Chernozem-derived material as one factor in the formation of these dark layers. However, Chernozem and Phaeozem soils are found in the catchment of the lower Weiße Elster valley where no black clay was formed (Tinapp et al., 2008). In contrast, for the Pleiße catchment where a black clay exists such soils do not exist today. Instead, Stagnogleys and Luvisols are the main soil types in the catchment of the lower Pleiße River and probably also existed prior to Neolithic settlement (von Suchodoletz et al., 2019). Therefore, for the lower Pleiße valley a genesis of the black clay from Chernozem- and Phaeozem-derived material can clearly be rejected.

\subsection{Alluvial overbank sedimentation since the Neolithic period}

The covering of the black clay by ca. $2.3 \mathrm{~m}$ of younger overbank deposits indicates an environmental change at all sites: the sedimentation of the black clay in an environment with fluctuating water tables in the floodplain passed over into the deposition of more silty and sandy material. Human deforestation and agricultural land use in the catchment of the Pleiße river since $5500 \mathrm{BCE}$ obviously resulted in the aggradation of coarser-grained and less organic overbank deposits that started between since ca. 4000 and ca. 3200 BCE (Fig. 7c and d). The growing thickness of the overbank fines led to less wet conditions and a more frequently dry topsoil. Similar to our results Rittweger (2000) dated the so-called Black Floodplain Soil into the Boreal and Atlantic period. He suggested relatively dry conditions after its formation, since the Black Floodplain Soil was strongly overprinted by soil development, and archaeological features on its surface proved human activities in the floodplain. However, that could be denied for the lower Pleiße valley: during the Early Neolithic period the floodplain was muddy and wet, and only the con- tinuous rise of the valley floors by subsequent overbank deposition allowed longer-lasting anthropogenic activities in the floodplain during a later period. Accordingly, the oldest archaeological features in the lower Pleiße valley originate from the Bronze Age (Grahmann and Braune, 1933). The moment of sedimentation change from the black clay to the overlying overbank deposits could obviously be detected by our thin section analysis: holes at the surface of the black clay must have been caused by rotten plant material (Fig. 6). These should derive from sedges that were bent over during a flood event and buried by the oldest overbank fines. During subsequent drier periods the organic material was decomposed, whereas the holes remained since bioturbation was prevented by the new sediment cover.

Similar to the neighbouring lower Weiße Elster floodplain where significant overbank sedimentation was recorded in ca. 4500 to 4000 BCE (Tinapp et al., 2008), this demonstrates a start of overbank sedimentation during the Neolithic period. Therefore, the fairly early start of overbank sedimentation obviously represents a regional reaction of the landscape in this part of central Germany following Neolithic settlement activities (Fig. 8). This demonstrates the dominant influence of quite intensive human activity on the development of overbank fines (Hiller et al., 1991; Tinapp, 2002; Tinapp et al., 2008), especially against the background that major climatic changes are not detectable in central Germany for this time (Litt, 1994; Wennrich, 2005).

The start of overbank sedimentation in central Germany already during the Neolithic period was significantly earlier than in many other catchments of central Europe, where despite Neolithic settlement activities this process started at the earliest between ca. 4.2 and ca. 2 ka (Rittweger, 2000; Niller, 2001; Mäckel et al., 2002; Fuchs et al., 2011; Houben et al., 2013; Notebaert et al., 2018; Brown et al., 2018). Delayed overbank sedimentation compared with the onset of Neolithic land use and the deposition of corresponding colluvial slope sediments in the latter is explained with temporally variable hydrosedimentary connectivity between hillslopes and floodplains, leading to a sediment cascade in the landscape (Brown, 2009; Fuchs et al., 2011; Houben et al., 2013). In contrast, the early start of overbank deposition in the Weiße Elster catchment was explained with good hillslope-channel coupling due to missing small sediment traps along the lower Weiße Elster valley since the Neolithic period (Tinapp et al., 2008). However, given the obviously regional character of early overbank sedimentation in this part of central Germany we think that other factors could have also caused the high regional Neolithic sediment connectivity. Possible factors could, for example, have been the spatial structure of regional Neolithic settlement activity or climatic factors in this relatively dry area with precipitation down to $500 \mathrm{~mm} \mathrm{a}^{-1}$. However, these are only hypotheses so far that need further investigations.

No clear sediment unconformities were detected in the overbank fines, although geomorphologically stable periods 


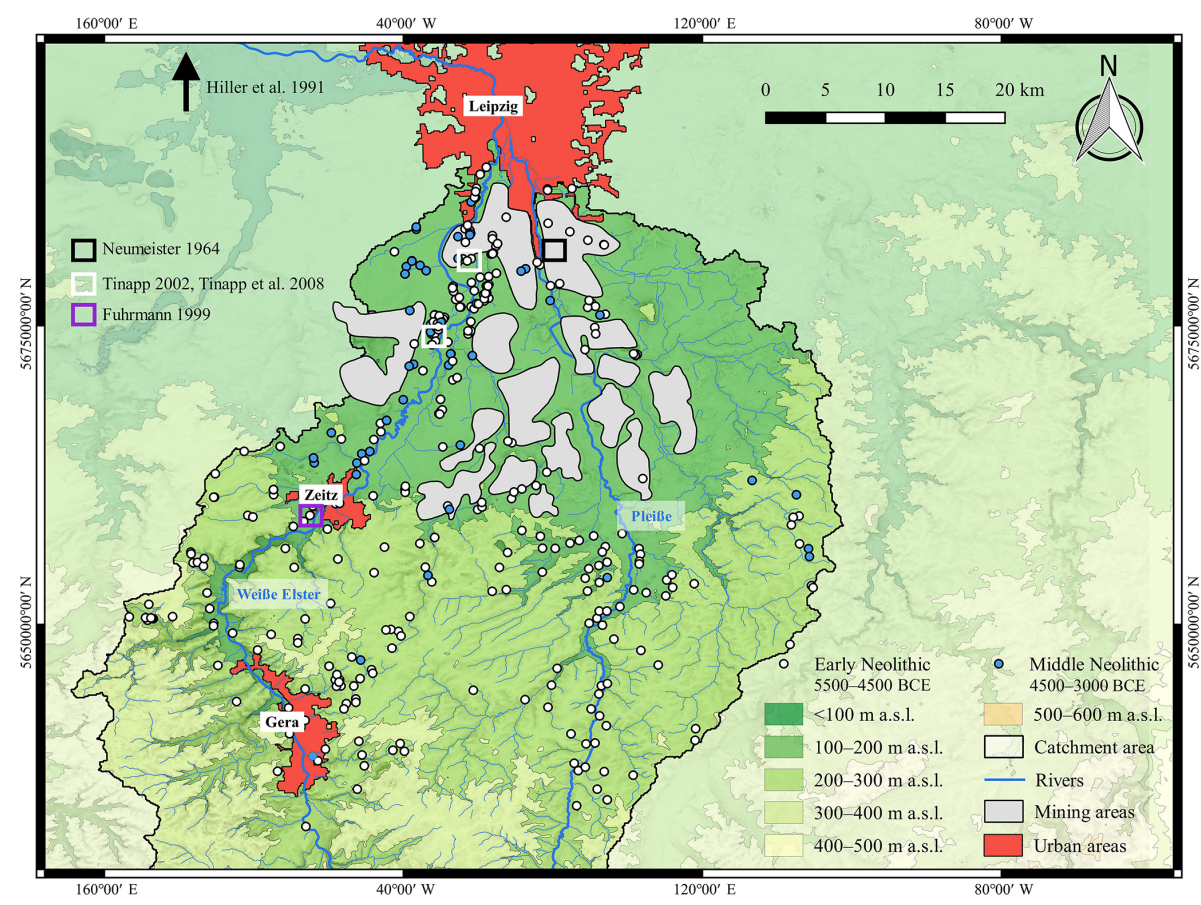

Figure 8. Early and Middle Neolithic find spots around the valleys of Weiße Elster and Pleiße and the positions of the main study sites. Mining activities destroyed great parts of the lower Pleiße floodplain and the surrounding plains, and most of these areas were archaeologically not investigated prior to 1993. The extent of the open cast mines on the map dates back to the year 1990 (Standke et al., 2010).

with less flooding often led to soil formation with the accumulation of organic material in floodplains of other regions (Zielhofer et al., 2009; May et al., 2015; von Suchodoletz et al., 2018b). Even at the Slavic level initial enrichment of organic material could not be detected (Fig. 5). Generally, unlike in many other river systems of western central Europe (Hoffmann et al., 2008; Fuchs et al., 2011; Houben et al., 2013; Notebaert et al., 2018) no strong increase of overbank sedimentation during the last 1000 years was observed along the lower Pleiße and Weiße Elster River: whereas at the lower Weiße Elster River ca. $0.8-1 \mathrm{~m}$ of overbank sediments compared with a total thickness of ca. 3-4 m was deposited over the last 1000 years (Fig. 7e), along the lower Pleiße River ca. $1 \mathrm{~m}$ of overbank sediments compared with a total thickness of ca. $2.3 \mathrm{~m}$ was observed. Thus, more than half of the finegrained sediment cover of these valleys was formed prior to the Middle Ages. Therefore, unlike in most other river systems of central Europe this demonstrates a relatively continuous high regional sediment connectivity in this part of central Germany since the Neolithic period.

\section{Conclusions}

Our investigations in the lower Pleiße valley were conducted at a mostly undisturbed site with predominant sedimentation and negligible erosion processes during the Holocene. We compared our results with those of Neumeister (1964) that were carried out less than $100 \mathrm{~m}$ east of our study site and that were based on field investigations that extended over ca. $900 \mathrm{~m}$. This comparison demonstrates that our investigated stratigraphy is representative of this part of the lower Pleiße valley, so we were able to build up a well-based reconstruction of its Holocene landscape development. In doing so, it was possible to define the turning point from extremely clayey and organic-rich, mostly limnic sedimentation (black clay) in the Boreal and Atlantic periods towards the deposition of coarser-grained and less organic overbank fines during the following period. This change occurred more than 1000 years after the beginning of Early Neolithic settlement between 4000 and 3300 BCE and was obviously linked with land clearance by these first farmers. The fairly early start of overbank sedimentation during the Neolithic period seems to be the exception rather than the rule in central Europe. During the following 6000 years sedimentation conditions did not change significantly (Fig. 4). Even initial organic enrichment could not be detected, although some geomorphologically stable periods with less flooding should have led to initial soil development. We also did not find a strong increase of the sediment deposition rates during and after the Middle Ages that was detected in many other catchments of central Europe, since more than half of the sediment cover of the lower Pleiße valley was deposited prior to that period. Further research in other river catchments of central Europe is needed to prove or to deny the singularity of the Holocene sedimentation history in the river catchments of lower Pleiße and Weiße Elster. 
Data availability. Data relating to this paper can be found in the Supplement.

Supplement. The supplement related to this article is available online at: https://doi.org/10.5194/egqsj-68-95-2019-supplement.

Author contributions. CT and HS organized the project. CT, SH and HvS carried out the fieldwork. The concept and structure of the paper were organized by CT and HvS. The laboratory work was done by $\mathrm{CH}$ (plant macro remains) and BS (geochemistry, particle size distribution). Thin section analysis were carried out by SH. Archaeological investigations were performed by HS and JM. CT and $\mathrm{HvS}$ took the lead in writing the manuscript, with input from $\mathrm{SH}$, $\mathrm{CH}$, BS and HS. All authors discussed the results and contributed to the final manuscript.

Competing interests. The authors declare that they have no conflict of interest.

Special issue statement. This article is part of the special issue "Connecting disciplines - Quaternary archives and geomorphological processes in a changing environment". It is a result of the First Central European Conference on Geomorphology and Quaternary Sciences, Gießen, Germany, 23-27 September 2018.

Acknowledgements. We thank Yvonne Heine and the excavation team. Constructive comments by Knut Kaiser and an anonymous reviewer helped us to improve the manuscript.

\section{References}

Bork, H.-R.: Die holozäne Relief- und Bodenentwicklung in Lössgebieten, Catena, Suppl.-Band, 1-93, 1983.

Bos, J. A. A., Dambeck, R., Kalis, A. J., Schweizer, A., and Thiemeyer, H.: Palaeoenvironmental changes and vegetation history of the northern Upper Rhine Graben (southwestern Germany) since the Lateglacial, Netherlands J. Geosc. Geol. Mijnb., 87, 65-88, 2008.

Bridgland, D. and Westaway, R.: Climatically controlled river terrace staircases: A worldwide Quaternary phenomenon, Geomorphology, 98, 285-315, 2008.

Brosche, K. H.: Zur jungpleistozänen und holozänen Entwicklung des Werratales zwischen Hannoversch Münden und Phillipsthal, Eiszeitalter u. Gegenwart, 34, 105-129, 1984.

Brown, A. G.: Colluvial and alluvial response to land use change in Midland England: an integrated geoarchaeological approach, Geomorphology, 108, 92-106, 2009.

Brown, A. G., Lespez, L., Sear, D. A., Macaire, J.-J., Houben, P., Klimek, K., Brazier, R. E., Van Oost, K., and Pears, B.: Natural vs anthropogenic streams in Europe: History, ecology and implications for restoration, river-rewilding and riverine ecosystem services, Earth-Sci. Rev., 180, 185-205, 2018.
Brunnacker, K.: Junge Deckschichten und 'schwarzerdeähnliche" Böden bei Schweinfurt, Geol. Bl. Nordost-Bayern, 9, 2-14, 1959.

Bullock, P., Fedoroff, N., Jongerius, A., Stoops, G., and Tursina, T. (Eds.): Handbook for soil thin section description, Waine Research Publications, Albrighton, Wolverhampton, 1985.

Cappers, R. T. J., Bekker, R. M., and Jans, J. E. A.: Digitale zadenatlas van Nederland - Digital seed atlas of the Netherlands, Groningen Archaeological Studies 4, 2nd edn., Barkhuis Publishing, Eelde, 2012.

Eissmann, L.: Quaternary geology of eastern Germany (Saxony, Saxon-Anhalt, South Brandenburg, Thüringia, type area of the Elsterian and Saalian stages in Europe, Quat. Sci. Rev., 21, 12751346, 2002.

Erkens, G., Dambeck, R., Volleberg, K. P., Bouman, M. T. I. J., Bos, J. A. A., Cohen, K. M., Wallinga, J., and Hoek, W. Z.: Fluvial terrace formation in the northern Upper Rhine Graben during the last 20000 years as a result of allogenic controls and autogenic evolution, Geomorphology, 103, 476-495, 2009.

Faust, D. and Wolf, D.: Interpreting drivers of change in fluvial archives of the Western Mediterranean - A critical review, EarthSci. Rev., 174, 53-83, 2017.

Fuchs, M., Will, M., Kunert, E., Kreutzer, S., Fischer, M., and Reverman, R.: The temporal and spatial quantification of Holocene sediment dynamics in a meso-scale catchment in northern Bavaria, Germany, The Holocene, 21, 1093-1104, 2011.

Fuhrmann, R.: Klimaschwankungen im Holozän nach Befunden aus Talsedimenten Mitteldeutschlands - Beiträge zur Klimageschichte und Stratigraphie des jüngeren Quartärs, Altenbg. nat.wiss. Forsch., 11, 3-41, 1999.

Fuhrmann, R.: Die Ostrakoden- und Molluskenfauna des Auelehmprofils Zeitz (Landkreis Burgenland) und ihre Aussage zum Klima sowie zur Landnutzung im jüngeren Holozän Mitteldeutschlands, Mauritiana, 20, 253-281, 2008.

Grahmann, R. and Braune, K.: Braune, Bronzezeitliche und slawische Herdstellen in der Pleißeaue bei Markkleeberg, "Die Fundpflege”, Jg. 1, H. 6, Beitrag d. Mitteldt. Bl. f. Volkskunde, 1933.

Händel, D.: Das Holozän in den nordwestsächsischen Flußauen, Hercynia, Bd. 4 Leipzig, 2, 152-198, 1967.

Heynowski, R. and Reiß, R. (Eds): Atlas zur Geschichte und Landeskunde von Sachsen, Beiheft zur Karte BI 1.1-1.5, Ur- und Frühgeschichte Sachsens, Leipzig/Dresden, 2010.

Hilgart, M.: Die geomorphologische Entwicklung des Altmühlund Donautales im Raum Dietfurt-Kelheim-Regensburg im jüngeren Quartär, Forschungen zur deutschen Landeskunde, 242, Deutsche Akademie für Landeskunde, Trier, 1995.

Hiller, A., Litt, T., and Eissmann, L.: Zur Entwicklung der jungquartären Tieflandstäler im Elbe-Saale-Gebiet unter besonderer Berücksichtigung von ${ }^{14} \mathrm{C}$-Daten, Eiszeitalter u. Gegenwart, 41, 26-46, 1991.

Hoffmann, T., Lang, A., and Dikau, R.: Holocene river activity: Analysing ${ }^{14} \mathrm{C}$-dated fluvial and colluvial sediments from Germany, Quaternary Sci. Rev., 27, 2031-2040, 2008.

Houben, P.: Sediment budget for five millennia of tillage in the Rockenberg catchment (Wetterau loess basin, Germany), Quaternary Sci. Rev., 52, 12-23, 2012. 
Houben, P., Schmidt, M., Mauz, B., Stobbe, A., and Lang, A.: Asynchronous Holocene colluvial and alluvial aggradation: A matter of hydrosedimentary connectivity, The Holocene, 23, 544-555, 2013.

Kaiser, K., Lorenz, S., Germer, S., Juschus, O. Küster, M, Libra, J., Bens, O. and Hüttl, R. F.: Late Quaternary evolution of rivers, lakes and peatlands in northeast Germany reflecting past climatic and human impact - an overview, Quaternary Sci. J., 61, 2, 103132, 2012.

Lauer, T. and Weiss, M.: Timing of the Saalian- and Elsterian glacial cycles and the implications for Middle- Pleistocene hominin presence in central Europe, Nature, Sci. Rep., 8, 5111, https://doi.org/10.1038/s41598-018-23541-w, 2018.

Litt, T.: Fresh investigations into the natural and anthropogenically influenced vegetation of the earlier Holocene in the ElbeSaale Region, Central Germany, Veg. Hist. Archaeobot., 1, 6974, 1992.

Litt, T.: Paläoökologie, Paläobotanik und Stratigraphie des Jungquartärs im nord-mitteleuropäischen Tiefland unter besonderer Berücksichtigung des Elbe-Saale-Gebietes, Dissertationes Botanicae, Halle, 227, 1994.

Mäckel, R., Schneider, R., Friedmann, A., and Seidel, J.: Envionmental changes and human impact on the relief development in the Upper Rhine valley and Black Forest (South-West Germany) during the Holocene, Z. Geomorphol., Supplement 128, 31-45, 2002.

Mania, D.: Zur spät- und nacheiszeitlichen Besiedlung in ihrer Beziehung zur natürlichen Umwelt, in: Wissenschaftliche Beiträge der Martin-Luther-Universität Halle-Wittenberg 1980/6, Halle/S, 29-31, 1980.

May, J.-H., Plotzki, A., Rodrigues, L., Preusser, F., and Veit, H.: Holocene floodplain soils along the Río Mamoré, northern Bolivia, and their implications for understanding inundation and depositional patterns in seasonal wetland settings, Sediment. Geol., 330, 74-89, 2015.

Mol, J.: Weichselian and Holocene river dynamics in relation to climate change in the Halle-Leipziger Tieflandsbucht (Germany), Eiszeitalter und Gegenwart, 45, 32-41, 1995.

Neumeister, H.: Beiträge zum Auenlehmproblem des Pleiße- und Elstergebietes, Wiss. Veröff. Dt. Inst. Länderkde., 21, 65-132, 1964.

Niller, H. P.: Wandel prähistorischer Landschaften, Erdkunde, 55, 32-48, 2001.

Notebaert, B., Broothaerts, N., and Verstraeten, G.: Evidence of anthropogenic tipping points in fluvial dynamics in Europe, Global Planet. Change, 164, 27-38, 2018.

Oberdorfer, E.: Pflanzensoziologische Exkursionsflora für Deutschland und angrenzende Gebiete, 8th edn., Ulmer, Stuttgart, 2001.
Pretzsch, K.: Spätpleistozäne und holozäne Ablagerungen als Indikatoren der fluvialen Morphodynamik im Bereich der mittleren Leine, Göttinger Geogr. Abh., Göttingen, 99, 1994.

Rittweger, H.: The "Black Floodplain Soil" in the Amöneburger Becken, Germany: a lower Holocene marker horizon and indicator of an upper Atlantic to Subboreal dry period in Central Europe?, Catena, 41, 143-164, 2000.

Schellmann, W.: Die Talentwicklung der unteren Oberweser im jüngeren Quartär, Düsseld. Geogr. Schr., 34, 11-43, 1994.

Schirmer, W.: Die Talentwicklung an Main und Regnitz seit dem Hochwürm, Geol. Jahrb., 71, 11-43, 1983.

Standke, G., Escher, D., Fischer, J., and Rascher, J: Das Tertiär Nordwestsachsens, Ein geologischer Überblick, LfULG Sachsen, Dresden, 2010.

Starkel, L., Soja, R., and Michczynska, D. J.: Past hydrological events reflected in Holocene history of Polish rivers, Catena, 66, 24-33, 2006.

Stoops, G.: Guidelines for analysis and description of soil and regolith thin sections, Soil Science Society of America, Inc., Madison, 2003.

Tinapp, C: Geoarchäologische Untersuchungen zur holozänen Landschaftsentwicklung der südlichen Leipziger Tieflandsbucht, Trierer Geographische Studien, 26, Trier, 2002.

Tinapp, C. and Stäuble, H.: Auenentwicklung und Besiedlungsgeschichte im Tal der Weissen Elster südlich von Leipzig, Trierer Geographische Studien, 23, 31-48, 2000.

Tinapp, C., Meller, H., and Baumhauer, R.: Holocene accumulation of colluvial and alluvial sediments in the Weiße Elster river valley in Saxony, Germany, Archaeometry, 50, 696-709, 2008.

von Suchodoletz, H., Gärtner, A., Zielhofer, C., and Faust, D.: Eemian and post-Eemian fluvial dynamics in the Lesser Caucasus, Quaternary Sci. Rev., 191, 189-203, 2018a.

von Suchodoletz, H., Zielhofer, C., Hoth, S., Umlauft, J., Schneider, B., Zeeden, C., Sukhishvili, L., and Faust, D.: North Atlantic influence on Holocene flooding in the southern Greater Caucasus, The Holocene, 28, 609-620, 2018b.

von Suchodoletz, H., Tinapp, C., Lauer, T., Glaser, B., Stäuble, H., Kühn, P., and Zielhofer, C.: Distribution of Chernozems and Phaeozems in Central Germany during the Neolithic period, Quat. Int., in press, https://doi.org/10.1016/j.quaint.2017.10.041, 2019.

Wennrich, V., Wagner, B., Melles, M., and Morgenstern, P.: Late Glacial and Holocene history of former Salziger See, Central Germany, and its climatic and environmental implications, Int. J. Earth Sci. (Geol Rundsch), 94, 275-284, 2005.

Zielhofer, C., Recio-Espejo, J. M., Nunez-Granados, M. A., and Faust, D.: Durations of soil formation and soil development indices in a Holocene Mediterranean floodplain, Quaternary Int., 209, 44-65, 2009. 